\title{
Influence of supplementation with two specific inactivated dry yeast and grape-skin extract on the color and composition of red wine
}

\author{
J. Gombau ${ }^{1}$, P. Pons ${ }^{1}$, D. Fernández ${ }^{1}$, J.M. Heras ${ }^{2}$, N. Sieczkowski ${ }^{2}$, J.M. Canals ${ }^{1}$, and F. Zamora ${ }^{1}$ \\ ${ }^{1}$ Departament de Bioquímica i Biotecnologia, Facultat d'Enologia de Tarragona, Universitat Rovira i Virgili, C/Marcel.li Domingo, \\ 1. 43007 Tarragona, Spain \\ ${ }^{2}$ Lallemand Bio S.L. C/ Galileu 303. 1a planta, 08028-Barcelona. España
}

\begin{abstract}
Wines from grapes of Cabernet Sauvignon of the AOC Tarragona were elaborated with supplementation or not of two specific inactivated dry yeasts (Optired ${ }^{\circledR}$ and Optimum $\operatorname{Red}^{\circledR}$; Lallemand Inc.) or with an experimental grape-skin extract. All the wines treated were significantly less astringent than the control wine because both inactivated dry yeast and the skin extract released polysaccharides which probably inhibit interactions between salivary proteins and tannins, and because their presence decrease the proportion of seed tannins and increase the proportion of skin tannins in the final wines.
\end{abstract}

\section{Introduction}

Nowadays supplementing red wines with commercial inactivated dry yeasts is a widespread practice in winemaking because it leads to better balanced wines through increased mouthfeel and smooth astringency.

This practice tries to reproduce what happens when the wines are aged in contact with lees in which yeast autolysis release significant amounts of polysaccharides and mannoproteins. In that sense, it has been described that wines aged in contact with lees or supplemented with commercial inactivated dry yeasts (IDY) has a significantly higher polysaccharide concentration $(11-20 \%)$ [1]. It is also generally accepted that this enrichment in polysaccharides is the reason of the improvement of the quality of red wines treated with IDY [2]. It has been also described that supplementation with IDY in grape juice during winemaking can significantly decrease the proanthocyanidin content of red wines $[3,4]$ reducing in sensory analysis the perception of green tannins, thereby increasing softness on the palate.

There are two main sources of polysaccharides in wine. One is the already mentioned yeasts autolysis (or supplementation with IDY) and the other one is the polysaccharides from grape cell walls [5]. Several studies have been published about how yeasts autolysis or supplementation with IDY affects the polysaccharide concentration and wine quality but little is known about the effect of supplementation with grape-skin extracts.

The aim of this work was to study the Influence of supplementation with two commercial IDY and an experimental grape-skin extract on the color and the composition of red wine.

\section{Materials and methods}

\subsection{Experimental design}

Grapes of Cabernet Sauvignon of the AOC Tarragona of vintage 2017 were harvested at the adequate maturity. The grapes were destemmed and randomly distributed in groups of $6 \mathrm{~kg}$ each. The grapes were crushed and sulphited $(50 \mathrm{mg} / \mathrm{L})$. A total of 12 microvinifications were carried out in $8 \mathrm{~L}$ tanks especially prepared for submerged cap winemaking [6]. All the tanks were inoculated with $200 \mathrm{mg} / \mathrm{L}$ of Saccharomyces cerevisiae strain (Lalvin EC1118 ${ }^{\circledR}$, Lallemand Inc.). Groups of three tanks were supplemented with $400 \mathrm{mg} / \mathrm{L}$ of Optired ${ }^{\circledR}$, Optimum Red ${ }^{\circledR}$ (Lallemand Inc.) or with $400 \mathrm{mg} / \mathrm{L}$ of an experimental grape-skin extract respectively, while the remaining three tanks were considered as controls. All microvinifications were performed at $27 \pm 1^{\circ} \mathrm{C}$ and after 15 days of maceration, the wines were racked, sulphited $(50 \mathrm{mg} / \mathrm{L})$, and refrigerated for one month at $4{ }^{\circ} \mathrm{C}$. Malolactic fermentation was inhibited to prevent possible variations in the rhythm of this transformation that could affect each sample differently. The wines were then decanted and bottled. All the samples were stocked at $15 \pm 1{ }^{\circ} \mathrm{C}$ until analysis.

\subsection{Chemical analyses}

The color intensity (CI), total phenolic index, total anthocyanins and PVPP Index were estimated using the methods described by Glories (1984) [7]. The CIELab coordinates, lightness $\left(\mathrm{L}^{*}\right)$, chroma $\left(\mathrm{C}^{*}\right)$, hue $\left(\mathrm{h}^{*}\right)$, redgreenness $\left(\mathrm{a}^{*}\right)$, and yellow-blueness $\left(\mathrm{b}^{*}\right)$, were determined according to the method used by Ayala et al. (1997) [8] and data processing was performed with MSCV software (Ayala et al., 2001) [9]. 
Table 1. General parameters, color and phenolic compounds.

\begin{tabular}{|l|c|c|c|c|}
\hline Parameter & Control & Optired $^{\circledR}$ & Optimum Red $^{\circledR}$ & Skin Extract \\
\hline Ethanol content $(\%)$ & $13.2 \pm 0.1 \mathrm{~A}$ & $13.4 \pm 0.21 \mathrm{~A}$ & $13.4 \pm 0.1 \mathrm{~A}$ & $13.4 \pm 0.4 \mathrm{~A}$ \\
\hline $\mathrm{pH}$ & $3.81 \pm 0.08 \mathrm{~A}$ & $3.75 \pm 0.01 \mathrm{~A}$ & $3.79 \pm 0.06 \mathrm{~A}$ & $3.8 \pm 0.03 \mathrm{~A}$ \\
\hline Titratable acidity (g tartaric acid/L) & $5.0 \pm 0.1 \mathrm{~A}$ & $5.4 \pm 0.1 \mathrm{~A}$ & $5.3 \pm 0.1 \mathrm{~A}$ & $5.3 \pm 0.1 \mathrm{~A}$ \\
\hline Color intensity & $14.0 \pm 0.1 \mathrm{~A}$ & $14.6 \pm 0.1 \mathrm{~A}$ & $14.0 \pm 0.9 \mathrm{~A}$ & $14.8 \pm 0.8 \mathrm{~A}$ \\
\hline Lightness $\left(\mathrm{L}^{*}\right)$ & $41.1 \pm 0.1 \mathrm{~A}$ & $41.2 \pm 0.7 \mathrm{~A}$ & $41.8 \pm 1.4 \mathrm{~A}$ & $41.1 \pm 0.8 \mathrm{~A}$ \\
\hline Chroma $\left(\mathrm{C}^{*}\right)$ & $51.6 \pm 0.4 \mathrm{~A}$ & $51.2 \pm 1.1 \mathrm{~A}$ & $51.3 \pm 0.8 \mathrm{~A}$ & $51.2 \pm 1.4 \mathrm{~A}$ \\
\hline Chroma $\left(\mathrm{C}^{*}\right)$ & $11.1 \pm 0.7 \mathrm{~A}$ & $12.0 \pm 0.5 \mathrm{~A}$ & $11.1 \pm 0.7 \mathrm{~A}$ & $11.9 \pm 0.5 \mathrm{~A}$ \\
\hline Anthocyanins $(\mathrm{mg} / \mathrm{L})$ & $191 \pm 13 \mathrm{~A}$ & $194 \pm 20 \mathrm{~A}$ & $193 \pm 6 \mathrm{~A}$ & $211 \pm 46 \mathrm{~A}$ \\
\hline TPI & $61.2 \pm 1.1 \mathrm{~A}$ & $63.6 \pm 2.7 \mathrm{~A}$ & $61.7 \pm 4.5 \mathrm{~A}$ & $62.2 \pm 1.8 \mathrm{~A}$ \\
\hline
\end{tabular}

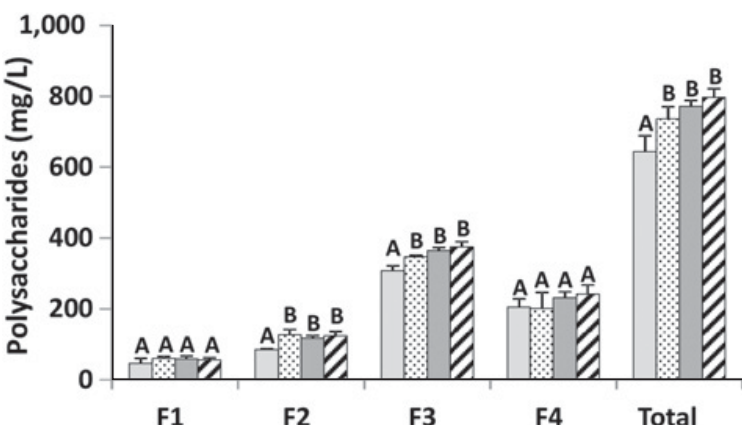

Results are expressed as mean \pm standard deviation of three replicates. $\square$ : Control; $\quad$ : $:$ Optired $^{\oplus} ; \quad \square$ : Optimum Red ${ }^{\oplus}$; : Skin Extract. F1: 144-1100 kDa; F2: 40-144 kDa; F3: 5-40 kDa; F4: 1-5 kDa. Different letters indicate a statistical difference $(p<0.05)$.

Figure 1. Polysaccharide composition.

Anthocyanins were analyzed by Reversed-phase HPLC in accordance with the method described by Gil et al. (2012) [10]. The total phenolic index (TPI) was determined by measuring absorbance at $280 \mathrm{~nm}$ [3].

The proanthocyanidins of the wines and their mean degree of polymerization (mDP), the percentage of prodelphinidins and the percentage of galloylation were analyzed by HPLC-DAD after acid depolymerization in the presence of an excess of phloroglucinol according with the method described by Kennedy and Jones (2001) [11].

The polysaccharides were determined by HRSEC-RID according with the methodology describer by Ayestaran et al. (2004) [12].

The astringency index was estimated using the method described by Llaudy et al. (2004) [13].

\section{Results and discussion}

\subsection{Color and phenolic compounds}

Table 1 shows the results corresponding to the color and phenolic compound composition of the different wines.

These results indicate that the supplementation with the two types of IDY or with the skin extract did not originate any significant change in any of these parameters.

\subsection{Polysaccharide composition}

Figure 1 shows the polysaccharide composition of the different wines.

As it can be seen, the supplementation with the two types of IDY and with the skins extract caused a significant increase in the concentration of total polysaccharides. The

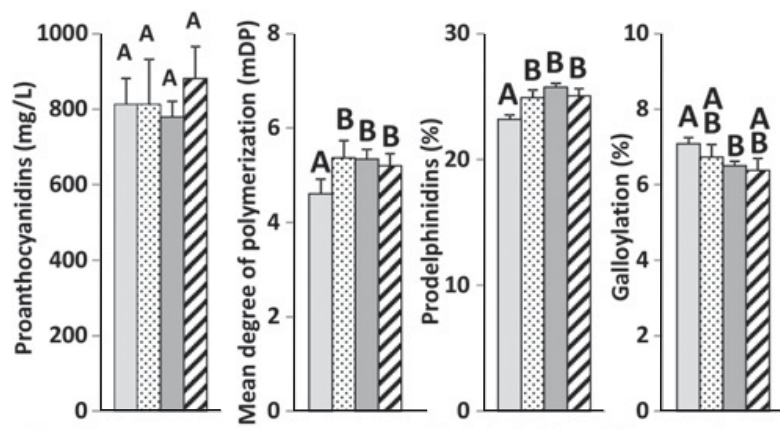

Results are expressed as mean \pm standard deviation of three replicates. $\square$ : Control; $\quad$ : Optired ${ }^{\circledast} ; \square$ : Optimum Red ${ }^{\oplus} ; \square$ : Skin Extract. Different letters indicate a statistical difference $(p<0.05)$.

Figure 2. Proanthocyanidin composition.

enrichment was mainly due to the fractions F2 and F3 with molecular weights between $40-144 \mathrm{kDa}$ and $5-40 \mathrm{kDa}$ respectively.

\subsection{Proanthocyanidin composition}

Figure 2 shows the proanthocyandin composition of the different wines.

No significant changes were detected in the total proanthocyanidin concentration of the treated wines in relation with the non-treated control. However supplementation with both IDY and with the skin extract caused significant increase of the mean degree of polymerization $(\mathrm{mDP})$ and of the percentage of prodelphinidins. Moreover, the percentage of galloylation tended to decrease in the treated wines although this reduction was only significant in the case of the wine treated with Optimum Red ${ }^{\circledR}$.

Since skin tannins are richer in prodelphinidins, and have higher $\mathrm{mDP}$ and a lower percentage of galloylation than seed tannins [10], these results suggest that the supplementation with these three sources of polysaccharides have increased the proportion of skin tannins and reduced the proportion of seed tannins in the treated wines.

\subsection{Astringency}

Figure 3 shows the astringency of the different wines measured by means of the ovalbumin index.

The results are very clear and indicate that the supplementation with both IDY and with the skin extract decreased significantly the astringency of these red wines. 


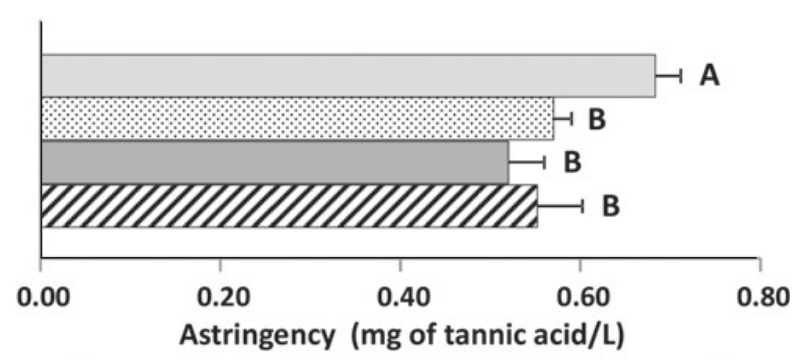

Results are expressed as mean \pm standard deviation of three replicates. $\square$ : Control; $\quad$ : Optired ${ }^{\star} ; \quad \square$ : Optimum Red ${ }^{\oplus} ; \quad \square$ : Skin Extract. Different letters indicate a statistical difference $(p<0.05)$.

Figure 3. Astringency.

\section{Conclusions}

It can be concluded that supplementation with both inactive yeasts or with the skin extract reduces wine astringency and modifies the wine composition. The action mechanism seems to be related to two different phenomena. In one hand, inactive yeasts and skin extract release polysaccharides and oligosaccharides which inhibit interactions between salivary proteins and tannins. And in the other hand, it seems that all these sources of polysaccharides increase the proportion of skin tannins, which are less astringent because they are richer in prodelphinidins and have a lower percentage of galloylation, and reduce the proportion of the more astringent tannins from seeds which does not contain prodelphinidins, have a lower $\mathrm{mDP}$ and a higher percentage of galloylation.

We would like to thank CICYT (Project AGL2014-56594-C2 -1-R) and CDTI (Program CIEN) "Nuevas estrategias vitivinícolas para la sostenibilidad y el incremento de la competitividad del sector en el mercado internacional (Project VINySOST 2014)."

\section{References}

[1] E. González, A. Urtasun, M. Gil, N. Kontoudakis, M. Esteruelas, F. Fort, J.M. Canals, F. Zamora, Am. J. Enol. Vitic. 64, 268 (2013)

[2] M. Gil, M. Quirós, F. Fort, P. Morales, R. González, J.M. Canals, F. Zamora, Am. J. Enol. Vitic. 66, 393 (2015)

[3] E. González-Royo, M. Esteruelas, N. Kontoudakis, F. Fort, J.M. Canals, F. Zamora, J. Sci. Food Agric. 97, 172 (2017)

[4] J. Mekoue-Nguela, N. Sieczkowski, S. Roi, A. Vernhet, J. Agric. Food Chem. 63, 660 (2015)

[5] F. Vidal, S.P. Williams, T. Doco, M. Moutounet, P. Pellerin, Carbohyd. Polym. 54, 439 (2003)

[6] T.L. Sampaio, J.A. Kennedy, M.C. Vasconcelos, Am. J. Enol. Vitic. 58, 534 (2007)

[7] Y. Glories, Conn. Vigne Vin. 18, 253 (1984)

[8] F. Ayala, J.F. Echavarri, A.I. Negueruela, Am. J. Enol. Vitic. 48, 357 (1997)

[9] F. Ayala, J.F. Echávarri, A.L. Negueruela, MSCVes. Zip, http: //www. unizar.es/negueruela/MSCV. es (2001)

[10] M. Gil, N. Kontoudakis, E. González, M. Esteruelas, F. Fort, J.M. Canals, F. Zamora, J. Agric. Food Chem. 60, 7988 (2012)

[11] J.A. Kennedy, G.P. Jones, J. Agric. Food Chem. 49, 1740 (2001)

[12] B. Ayestarán, Z. Guadalupe, D. León, Anal. Chim. Acta 513, 29 (2004)

[13] M.C. Llaudy, R. Canals, J.M. Canals, N. Rozés, L. Arola, F. Zamora, J. Agric. Food. Chem. 52, 742 (2004) 